\title{
Phylogeny of Poaceae Inferred from matK Sequences
}

\author{
Khidir W. Hilu; Lawrence A. Alice; Hongping Liang \\ Annals of the Missouri Botanical Garden, Vol. 86, No. 4. (Autumn, 1999), pp. 835-851.
}

Stable URL:

http://links.jstor.org/sici?sici=0026-6493\%28199923\%2986\%3A4\%3C835\%3APOPIFM\%3E2.0.CO\%3B2-D

Annals of the Missouri Botanical Garden is currently published by Missouri Botanical Garden Press.

Your use of the JSTOR archive indicates your acceptance of JSTOR's Terms and Conditions of Use, available at

http://www.jstor.org/about/terms.html. JSTOR's Terms and Conditions of Use provides, in part, that unless you have obtained prior permission, you may not download an entire issue of a journal or multiple copies of articles, and you may use content in the JSTOR archive only for your personal, non-commercial use.

Please contact the publisher regarding any further use of this work. Publisher contact information may be obtained at http://www.jstor.org/journals/mobot.html.

Each copy of any part of a JSTOR transmission must contain the same copyright notice that appears on the screen or printed page of such transmission.

The JSTOR Archive is a trusted digital repository providing for long-term preservation and access to leading academic journals and scholarly literature from around the world. The Archive is supported by libraries, scholarly societies, publishers, and foundations. It is an initiative of JSTOR, a not-for-profit organization with a mission to help the scholarly community take advantage of advances in technology. For more information regarding JSTOR, please contact support@jstor.org. 


\title{
PHYLOGENY OF POACEAE INFERRED FROM matK SEQUENCES ${ }^{1}$
}

Khidir W. Hilu', Lawrence A. Alice ${ }^{2.3}$, and Hongping Liang ${ }^{2}$

\begin{abstract}
Complete sequences of the plastid gene mat $\mathrm{K}$ were determined for 62 species of Poaceae from 60 genera, 26 tribes, and nine subfamilies to infer phylogenetic relationships. Restio tetraphyllus (Restionaceae) and Joinvillea ascendens (Joinvilleaceae) were used as outgroups. Cladistic analysis using PAUP yielded 39 most parsimonious trees with several well-supported major lineages. The strict consensus tree shows Streptochaeta and Anomochloa forming the two most basal lineages in grasses, followed by Pharus being sister to the remaining species. The other grasses divide into three clades: (1) subfamily Bambusoideae (excluding Brachyelytrum) plus Pooideae; (2) Oryzoideae; and (3) subfamilies Panicoideae, Arundinoideae, Centothecoideae, and Chloridoideae (termed PACC). Except for Arundinoideae, monophyly of each PACC subfamily is generally well supported; however, relationships among subfamilies are unresolved or weakly supported. Results obtained using matK sequences are largely consistent with other phylogenies based on molecular and structural data, particularly in that relationships among subfamilies remain unclear.
\end{abstract}

Interest in the evolution of grasses began early in this century with proposed hypotheses based on assessment of existing knowledge of the family (e.g., Bew, 1929; Hubbard, 1948; Stebbins, 1956, 1982; Prat, 1960; Clayton, 1981; Tsvelev, 1983). Empirical approaches to phylogenetic reconstruction of the Poaceae followed those initial hypotheses, starting with cladistic analyses of morphological and anatomical characters (Baum, 1987; Kellogg \& Campbell, 1987; Kellogg \& Watson, 1993). Recently, molecular data have provided the grounds for phylogenetic hypotheses in grasses at the subfamilial and tribal levels. These studies were based on information from chloroplast DNA (cpDNA) restriction sites and DNA sequencing of the $r b c \mathrm{~L}, n d h \mathrm{~F}, r p s 4, r p o \mathrm{C} 2, m a t \mathrm{~K}$, nuclear ribosomal DNA (nrDNA) 18S and 26S, phytochrome, and granule-bound starch synthase genes, as well as the noncoding nrDNA Internal Transcribed Spacer (ITS) region (Hamby \& Zimmer, 1988; Doebley et al., 1990; Davis \& Soreng, 1993; Cummings et al., 1994; Hsiao et al., 1994; Nadot et al., 1994; Barker et al., 1995, 1999; Clark et al., 1995; Duvall \& Morton, 1996; Liang \& Hilu, 1996; Mathews \& Sharrock, 1996; Mason-Gamer et al., 1998; Soreng \& Davis, 1998; Hsiao et al., 1999).

Although these studies have refined our under- standing of grass evolution at the subfamilial level and, to a certain degree, at the tribal level, major questions remain to be resolved. Although the basal positions of Anomochloeae, Phareae, and Streptochaeteae have been established, their relative placement and taxonomic status are debatable. Uncertainties also exist concerning the phylogenetic affinities among subfamilies and the taxonomic rank of others such as the Oryzoideae.

In this study, the chloroplast mat $\mathrm{K}$ gene was chosen to address these and other questions pertaining to higher-level grass systematics. The mat $\mathrm{K}$ gene is $\sim 1515$ base pairs (bp) in most angiosperms, located within the $t r n \mathrm{~K}$ intron, and functionally may be involved in splicing group II introns (Neuhaus \& Link, 1987; Ems et al., 1995; Hilu \& Alice, in press a). The effective application of this gene in plant systematics (e.g., Johnson \& Soltis, 1994, 1995; Hilu \& Liang, 1997; Kron, 1997) and grasses (Liang \& Hilu, 1996; Hilu \& Alice, in press a, b) has already been documented. mat $\mathrm{K}$ is known to have relatively high rates of substitution compared to other chloroplast genes (see Olmstead \& Palmer, 1994; Johnson \& Soltis, 1995). This gene exhibits a relatively high proportion of transversions, and the $3^{\prime}$ region of its open reading frame $(\mathrm{ORF})$ has

${ }^{1}$ We thank Nigel Barker, Lynn Clark, Travis Columbus, Jerry Davis, Tarciso Filgueiras, Gary Fleming, Surrey Jacobs, David Knepper, A. Nishiwaki, John Randall, Thomas Wieboldt, the Botanical Garden at Bonn, and the Missouri Botanical Garden for supplying DNA or plant samples. Seed material for some accessions was kindly provided by the U.S. Department of Agriculture, Agriculture Research Service-National Plant Germplasm System. We also thank Gerasimo Borneo, Thomas Borsch, Gerrit Davidse, John MacDougal, and Christoph Neinhuis for their assistance. This work was supported by NSF grant \#DEB-9634231 and Sigma Xi.

2 Department of Biology, Virginia Polytechnic Institute and State University, Blacksburg, Virginia 24061-0406, U.S.A.

${ }^{3}$ Current address: Department of Biology, Western Kentucky University, Bowling Green, Kentucky 42101, U.S.A. 


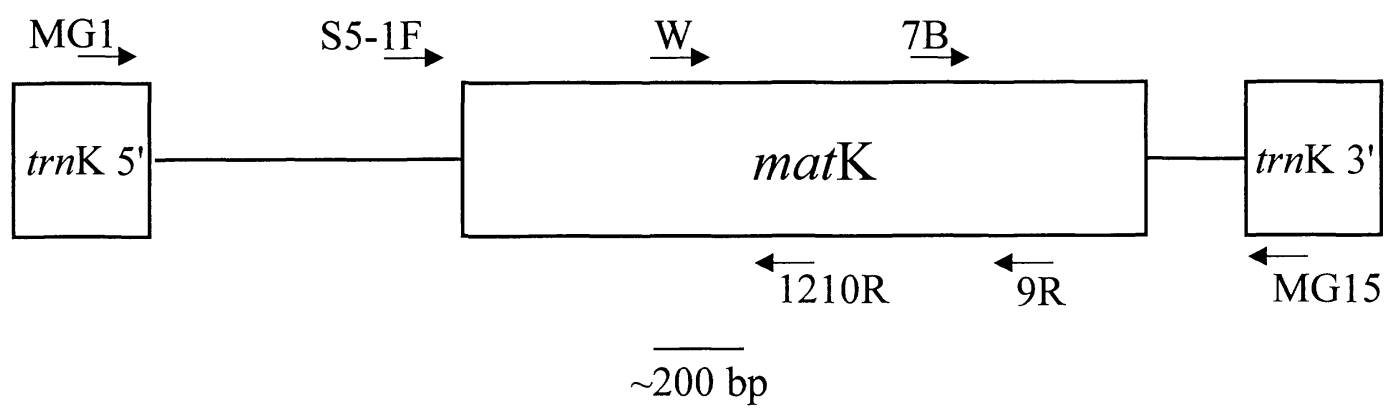

Figure 1. Diagram of the trnK region including the matK gene. PCR and sequencing primers are indicated with arrows. Primer sequences are: MG1 = CTACTGCAGAACTAGTCGGATGGAGTAGAT; MG15 = ATCTGGGTTGCTAACTCAATG; S5-1F = ACCCTGTTCTGACCATATTG; 1210R = GTAGTTGAGAAAGAATCGC; W = TACCCTATCCTATCCAT; 7B = GATTTATCA/GGATTGGGAT; and 9R = TACGAGCTAAAGTTCTAGC. trnK exons and primers are not drawn to scale.

been demonstrated to be quite useful in resolving subfamilial, and to a certain degree, tribal relationships in Poaceae (Liang \& Hilu, 1996).

\section{Materials And Methods}

\section{PLANT SAMPLES}

We sequenced the entire matK gene of 62 Poaceae species representing 60 genera, 26 tribes, and nine subfamilies (Appendix 1). Subfamilial and tribal classification generally follows Clayton and Renvoize (1986). Restio tetraphyllus (Restionaceae) and Joinvillea ascendens (Joinvilleaceae) were used as outgroups because recent studies have demonstrated that these two families are closely related to grasses (Doyle et al., 1992; Kellogg \& Linder, 1995; Soreng \& Davis, 1998, and references therein).

\section{DNA ISOLATION, POLYMERASE CHAIN REACTION (PCR) AMPLIFICATION, AND SEQUENCING}

Leaf tissue was harvested from either greenhouse-grown plants, field-collected plants, or herbarium specimens. Total cellular DNA was isolated following M'Ribu and Hilu (1996). Because the mat $\mathrm{K}$ gene is part of the $\operatorname{trnK} \mathrm{K}$ intron, we used two primers (MG1 or trnK3914 and MG15), located in the $\operatorname{trnK} 5^{\prime}$ and $3^{\prime}$ exons, respectively, for PCR amplification. For sequencing, trnK region PCR products were electrophoresed in $0.8 \%$ agarose gels and DNA fragments of appropriate size excised and purified using a QIAquick gel extraction kit (QIAGEN, Inc., Valencia, California). For each accession, the entire $m a t \mathrm{~K}$ coding region was sequenced, utilizing three to six primers (Fig. 1). Sequencing reactions were carried out using two different $\mathrm{ABI}$

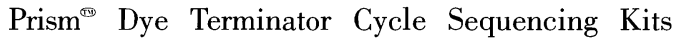
(Perkin Elmer, Norwalk, Connecticut). Most sam- ples were electrophoresed in an ABI 373A automated DNA sequencer with a stretch gel or in an ABI 310 Genetic Analyzer (Applied Biosystems, Inc., Foster City, California). Resulting chromatograms were manually edited using Sequence Navigator 1.0 software (Applied Biosystems Inc., Foster City, California). Sequences were deposited in GenBank (see Appendix 1).

\section{SEQUENCE ALIGNMENT AND PHYLOGENETIC ANALYSIS}

Alignment of complete mat $\mathrm{K}$ sequences was unambiguous and, thus, done manually. Twelve gaps varying in length from 1 to $9 \mathrm{bp}$ were required to align sequences (Table 1). Non-random structure in the data was tested by using the random trees option in PAUP*4.0b2a (Swofford, 1998). The $g_{1}$ value for the distribution of tree lengths of 100,000 random trees was compared using the critical value (at $\alpha=0.05$ ) for 500 variable characters and 25 taxa. Beyond 15 taxa, $g_{1}$ critical values change only slightly, allowing them to be used in a conservative test with more taxa (Hillis \& Huelsenbeck, 1992).

Phylogenies were generated using Fitch parsimony as implemented in PAUP, employing heuristic searches consisting of 1000 replicates of random stepwise addition of taxa with MULPARS on and tree-bisection-reconnection (TBR) branch swapping. Gaps were treated as missing data. Sets of equally parsimonious trees were summarized by strict consensus. Parsimony-informative gaps are mapped onto the strict consensus cladogram (Fig. 2 ). Because the transition/transversion ratio (ns/nv) in this $m a t \mathrm{~K}$ data set is $1.33: 1.0$, all characters were equally weighted. The $\mathrm{ns} / \mathrm{nv}$ was calculated with MacClade 3.01 (Maddison \& Maddison, 1992) and based on the strict consensus tree. To explore the effects of positional weighting, third positions of codons were downweighted to one-half that of 
Table 1. List of 12 gaps required for alignment of matK sequences of the outgroups Restio tetraphyllus and Joinvillea ascendens, and 62 Poaceae species. Gap codes $(\mathrm{a}-\mathrm{l})$ are used in the text and Figure 2. Each gap was determined to be an insertion (I) or a deletion (D) based on the strict consensus phylogeny (Fig. 2). Position ( $\left.5^{\prime} \rightarrow 3^{\prime}\right)$ is based on the overall number of aligned nucleotides (1576). * indicates parsimony-informative indels.

\begin{tabular}{rlccc}
\hline \hline Code & \multicolumn{1}{c}{ Taxa } & Gap & Length (bp) & Position \\
\hline $\mathrm{a}$ & Pharus & $\mathrm{I}$ & 6 & $4-9$ \\
$* \mathrm{~b}$ & All Poaceae & $\mathrm{D}$ & 9 & $127-135$ \\
$* \mathrm{c}$ & Leymus, Triticum & $\mathrm{I}$ & 3 & $154-156$ \\
$\mathrm{~d}$ & Joinvillea, all Poaceae & $\mathrm{I}$ & 3 & $163-165$ \\
$\mathrm{e}$ & Echinochloa & $\mathrm{I}$ & 3 & $166-168$ \\
$\mathrm{f}$ & Lithachne & $\mathrm{D}$ & 3 & $283-285$ \\
$\mathrm{~g}$ & Zizania & $\mathrm{I}$ & 6 & $829-834$ \\
$* \mathrm{~h}$ & Hyparrhenia, Sorghum & $\mathrm{I}$ & 6 & $1471-1476$ \\
$\mathrm{i}$ & Ehrharta & $\mathrm{D}$ & 1 & 1552 \\
$* \mathrm{j}$ & All Poaceae except Anomochloa, Streptochaeta & $\mathrm{D}$ & 1 & 1559 \\
$\mathrm{k}$ & Restio & $\mathrm{D}$ & 3 & $1561-1563$ \\
$* \mathrm{l}$ & PACC & $\mathrm{I}$ & 6 & $1564-1569$ \\
\hline
\end{tabular}

first and second positions. Decay indices (Bremer, 1988; Donoghue et al., 1992) and bootstrap values (Felsenstein, 1985), based on 100 replicates, were calculated as measures of support for individual clades. Decay analyses were performed with AutoDecay (Eriksson \& Wikstrom, 1996), using the reverse constraint option in PAUP. The data set was also analyzed with a Neighbor-Joining (NJ) approach utilizing Jukes-Cantor (1969) and Kimura 2-parameter (1980) distance estimates.

\section{RESUlts}

\section{MATK LENGTH, GC CONTENT, SEQUENCE DIVERGENCE, AND NUCLEOTIDE SITE VARIATION}

The mat K ORF in the species examined ranges in length from $1521 \mathrm{bp}$ (Ehrharta) to $1548 \mathrm{bp}$ ( $\mathrm{Hy}$ parrhenia and Sorghum). However, most species have an ORF of 1536-1542 bp. Mean guanine + cytosine $(\mathrm{G}+\mathrm{C})$ content is $\sim 32 \%$. Pairwise divergence of sequences ranges from 7.3 to $22.3 \%$ between the outgroups and Poaceae and 0.46 to $11.9 \%$ within Poaceae. Of the overall 1576 aligned characters, $836(53.0 \%)$ are variable and 520 $(33.0 \%)$ are parsimony informative. In Poaceae 764 $(48.8 \%)$ characters are variable and $473(30.0 \%)$ are parsimony informative. The first, second, and third positions of codons comprise 30.7, 25.6, and $43.7 \%$ of the variable sites, respectively, and account for $28.5,23.1$, and $48.4 \%$ of the parsimonyinformative sites.

\section{PHYLOGENY OF POACEAE}

Evidence of non-random structure in the $\mathrm{Po}$ aceae $m a t \mathrm{~K}$ data set is significant $(P<0.01)$ based on the $g_{1}$ value $(-0.376)$. Cladistic analysis with gaps coded as missing data yielded 39 equally parsimonious trees 2163 steps in length (strict consensus in Fig. 2). The Consistency Index (CI) and Retention Index (RI), excluding uninformative characters, are 0.453 and 0.700 , respectively. Based on the polynomial regression of Sanderson and Donoghue (1989), the estimated CI for 64 taxa is 0.364; therefore, levels of homoplasy in our data set are lower than predicted. Their regression is limited to 60 or fewer taxa, and expected CIs for 44 and 60 taxa are virtually identical $(0.344$ and 0.347 , respectively). Thus, the expected CI value for 64 taxa according to Sanderson and Donoghue's (1989) regression may be inflated.

The strict consensus tree (Fig. 2) shows Streptochaeta and Anomochloa to be the two most basal lineages, followed by Pharus as sister to the other grasses. The remaining species assort into three well-supported lineages. One clade includes members of Bambusoideae and Pooideae (including Brachyelytrum; Bambusoideae), another contains Oryzoideae (including Ehrharta, Ehrharteae), and a third clade comprises subfamilies Panicoideae, Arundinoideae, Centothecoideae, and Chloridoideae (PACC). Among the three clades, the PACC group has the greatest support with a bootstrap value of $100 \%$ and a decay index of 13 .

The bambusoid-pooid clade is well supported (88\% bootstrap and decay of 4) and divided into two lineages: one corresponding to the Bambusoideae and the other to Brachyelytrum + Nardus and other Pooideae. Within the Bambusoideae, Sasa and Phyllostachys (both Bambuseae) form a strongly supported subclade (100\% bootstrap) as do Par- 
iana (Parianeae) and Lithachne + Olyra (both Olyreae). However, Chusquea (Bambuseae) emerges as an unresolved lineage. Brachyelytrum (Bambusoideae, Brachyelytreae; sensu Clayton \& Renvoize, 1986) and Nardus (Pooideae; Nardeae) form a clade that is sister to the remaining Pooideae; this clade is supported with an $81 \%$ bootstrap value and a decay index of 3 . The other pooids appear in a trichotomy including: Stipa + Nassella (Stipeae); Melica (Meliceae); and a large, well-supported clade comprising Bromeae (Bromus) + Triticeae (Hordeum, Leymus, and Triticum) in one subclade and Poeae (Poa and Vulpia) + Aveneae (Avena and Phalaris) in another subclade. The positions of Bri$z a$ (Poeae) and Phleum (Aveneae) are unusual in that Briza clusters with the Aveneae and Phleum with the Poeae. Subfamily Oryzoideae appears monophyletic (100\% bootstrap and decay 10) with Ehrharta sister to Oryza + Zizania. The Oryzoideae lie sister to the PACC clade, although bootstrap $(<50 \%)$ and decay (1) support is low.

In a strongly supported PACC clade, Aristida appears basal, but bootstrap and decay support is low (Fig. 2). Following this group are four unresolved lineages: (1) Arundo, (2) Phragmites + Molinia, (3) subfamilies Centothecoideae and Panicoideae, and (4) Danthonia, Centropodia, + subfamily Chloridoideae. Monophyly of the Centothecoideae is not well supported (74\% bootstrap and decay of 1), yet support for the Zeugites-Lophatherum-Orthoclada subclade is very strong (bootstrap value of $100 \%$ with a decay index of 15). The Panicoideae do not appear monophyletic because Loudetiopsis (Arundinelleae) appears as an unresolved lineage separate from the Centothecoideae and Panicoideae. Aside from Loudetiopsis, the panicoid grasses are strongly supported with a bootstrap value of $95 \%$ and a decay index of 4 . The Panicoideae divide into two subclades: (1) Paniceae (Digitaria, Panicum, and Echinochloa); and (2) the apparently paraphyletic Andropogoneae (Zea, Sorghum, Hyparrhenia, and Andropogon), with Tristachya (Arundinelleae) sister to the latter three genera. Support for the monophyly of, and relationships among, the Centothecoideae, Panicoideae, and Loudetiopsis is low.

The association of Danthonia and Centropodia (both Arundinoideae) with subfamily Chloridoideae has reasonable support (bootstrap value of $62 \%$ and a decay index of 2 ) based on mat $\mathrm{K}$ data. The Chloridoideae are very strongly supported $(100 \%$ bootstrap and decay of 10) as a monophyletic lineage. Within the chloridoid clade are three well-defined subclades, including Uniola, Pappophorum, and Eragrostis as sister to the other species, Sporobolus + Zoysia, and a third subclade containing the re- maining members of the Chlorideae, Eragrostideae, and Orcuttieae. The only well-supported structure within this latter group is a clade including Astrebla, Chloris, and Microchloa (97\% bootstrap and decay 5).

When third positions of codons are downweighted (tree not shown) there is a general loss of resolution among the Arundinoideae taxa at the base of the PACC clade, Loudetiopsis emerges unresolved and separate from the centothecoid-panicoid clade, and the Oryzoideae occupy an intermediate position between the Bambusoideae-Pooideae clade and PACC. The NJ analysis based on Jukes-Cantor and Kimura 2-parameter distances yielded trees identical in topology to each other (Fig. 3) and that are largely consistent with the parsimony phylogeny (Fig. 2). Most differences are matters of increased resolution, such as the relationships among PACC subfamilies, and the positions of Chusquea and Melica. Topological disagreement does exist concerning the positions of Orcuttia and Tristachya. In the parsimony tree Orcuttia is weakly supported (bootstrap $<50 \%$ and decay 2) as sister to Bouteloua; however, in the NJ tree Orcuttia clusters with Kengia. The difference in the position of Tristachya between the parsimony and NJ analyses is minor, involving only a switch with the adjacent Sorghum concerning the sister relationship to Andropogon + Hyparrhenia.

\section{INSERTIONS AND DELETIONS (INDELS) IN MATK}

The incorporation of 12 gaps was necessary to align the matK sequences of Restio, Joinvillea, and Poaceae. From the strict consensus tree (gaps coded as missing data), seven insertions and four deletions were determined (Table 1). Another 3-bp gap (k) in Restio was identified as a deletion based on a broader sampling of mat $\mathrm{K}$ sequences (Hilu \& Alice, in press a). Five of these indels are parsimony-informative (three insertions and two deletions), of which four are synapomorphic. These synapomorphic indels include the 9-bp deletion (b) uniting the Poaceae, the 1-bp deletion (j) distinguishing Streptochaeta and Anomochloa from all other grasses, the 6-bp insertion (l) characterizing the PACC clade, and the 3-bp insertion (c) present in Leymus and Triticum. The 6-bp insertion (h) found in Hyparrhenia and Sorghum is homoplasious. The two indels that are not a multiple of three (i and j; both are single base deletions) occur near the $3^{\prime}$ end of the mat $\mathrm{K}$ gene and, thus, do not have a major impact on protein composition (Hilu \& Alice, in press a). Among the remaining indels, six $(a-f)$ are located within the first 285 nucleotide 
sites of the $5^{\prime}$ region, one $(\mathrm{g})$ is found at sites 829 834, and three indels (h, k, and l) occur within $\sim 100$ sites of the $3^{\prime}$ end of the gene.

\section{Discussion}

Analyses of the mat $\mathrm{K}$ sequences for the 62 grass species demonstrate again the high rate of substitution in this gene. The $764(48.8 \%)$ variable and $473(30.0 \%)$ parsimony-informative positions contribute a considerable number of characters for resolving the phylogeny of the Poaceae. This data set is considerably larger than the one used in the exploratory matK study of Liang and Hilu (1996) in which 17 species were analyzed with 583 nucleotides, of which 87 were parsimony-informative. The overall $\mathrm{ns} / \mathrm{nv}$ is 1.33 for the whole $m a t \mathrm{~K}$ gene. This $\mathrm{ns} / \mathrm{nv}$ ratio is lower than the 1.79 value obtained by Liang and Hilu (1996) from the $3^{\prime}$ region, but is in line with the $1.01 \mathrm{~ns} / \mathrm{nv}$ ratio calculated by Hilu and Liang (1997) for the whole matK gene of various plant taxa. The relatively large number of transversion mutations detected in the whole $m a t \mathrm{~K}$ gene of Poaceae appears to be a reflection of differential rates of transversion mutations in different sectors of the gene (K. Hilu, unpublished data).

\section{BASAL LINEAGES IN POACEAE}

The Bambusoideae were traditionally considered the most ancestral group of grasses, but the presence of derived anatomical, vegetative, and some reproductive characters led Soderstrom (1981) to state that the Bambusoideae are a specialized group. Soderstrom (1981) also stated that among Bambusoideae the herbaceous Streptochaeta has long been regarded as the most primitive grass. Kellogg and Campbell (1987) raised the possibility of a most basal position for the "herbaceous bambusoids," while Kellogg and Watson (1993) maintained that the Bambusoideae cannot be both basal and monophyletic.

Using data from $n d h \mathrm{~F}$ sequences and cpDNA restriction sites alone or in combination with structural (anatomy, gross morphology, physiology, and chloroplast genome structural mutations) characters, Streptochaeta + Anomochloa, and Pharus (traditionally considered as herbaceous bamboos) emerged as basal lineages with Pharus sister to other grasses (Clark et al., 1995; Soreng \& Davis, 1998). Duvall and Morton (1996) also cited support for a basal position of Anomochloa based on $r b c \mathrm{~L}$ sequences (Streptochaeta and Pharus were not sampled). Additionally, the ITS study by Hsiao et al. (1999) supports the basal positions of Streptochaeta and Pharus (Anomochloa was not sampled). Clark and Judziewicz (1996) placed Anomochloa (Anomochloeae) and Streptochaeta (Streptochaeteae) in subfamily Anomochlooideae and established subfamily Pharoideae to encompass the Phareae.

Although this study shows Streptochaeta as the most basal genus in Poaceae, it does not support the monophyly of Anomochloa and Streptochaeta as shown by Clark et al. (1995) and in Soreng and Davis's (1998) molecular and combined analyses. Cladistic analysis of 42 structural characters is consistent with our matK results (Soreng \& Davis, 1998). Support for the separation of these two genera as distinct lineages based on $m a t \mathrm{~K}$ sequences is reasonable (bootstrap value of $78 \%$ and a decay index of 3) and, therefore, these data argue against monophyly of the Anomochlooideae sensu Clark and Judziewicz (1996). Clark and Judziewicz asserted that it is not easy to find anatomical and morphological synapomorphies to define this clade. The position of Pharus in the mat $\mathrm{K}$ phylogeny is in agreement with all studies that have included this taxon. However, in Soreng and Davis's (1998) analysis of structural characters, Pharus was unresolved with Eremitis and these appear as sister to other grasses. Pharus also appeared distinct from all 215 grass genera (including the Bambusoideae) in the numerical study of Hilu and Wright (1982) that was based on 85 structural characters.

\section{DEEP BIFURCATION IN GRASS PHYLOGENY}

When Streptochaeta, Anomochloa, and Pharus are excluded from consideration, a split of grasses into two lineages is evident, yet the composition of the groups varied (Davis \& Soreng, 1993; Cummings et al., 1994; Clark et al., 1995). The phylogeny based on cpDNA restriction sites (Davis \& Soreng, 1993) depicted two lineages, one corresponding to the Pooideae and the other including all remaining grass taxa. The alliance of the Bambusoideae-Oryzoideae clade with the PACC group in the second major lineage was unstable, and the overall topology of the tree changed considerably after the exclusion of one restriction site (Davis \& Soreng, 1993, figs. 2, 3). In a subsequent cpDNA and structural data study, a bifurcation was not evident (Soreng \& Davis, 1998). Cummings et al. (1994) reported a phylogeny based on the rpoC2 gene, showing two major grass lineages: (1) Pooideae $+Z e a$ (Panicoideae) and (2) Oryzoideae-Panicoideae-Arundinoideae-Chloridoideae. The tree was rooted with spinach and tobacco, two very distant taxa.

Clark et al. (1995) resolved a bifurcation in the family following Streptochaeta + Anomochloa and 


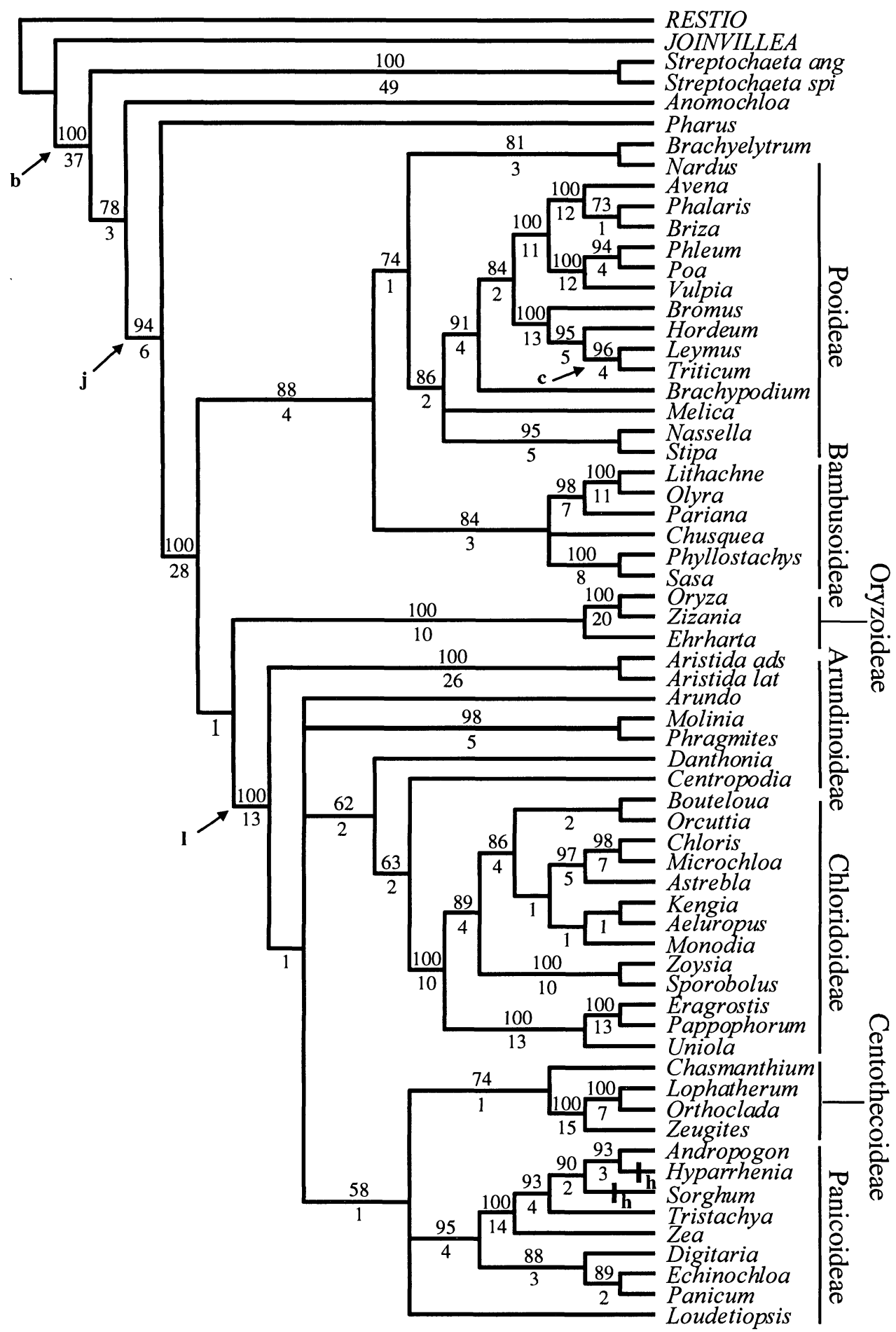

Figure 2. Strict consensus of 39 equally parsimonious trees including 62 Poaceae species and the two outgroups Restio tetraphyllus and Joinvillea ascendens (shown in uppercase). Aristida ads = A. adscensionis, Aristida lat $=$ A. latifolia, Streptochaeta ang $=S$. angustifolia, and Streptochaeta spi $=S$. spicata. Parsimony-informative indels are indicated with bold, lowercase letters: $\mathrm{b}=9$-bp deletion, $\mathrm{c}=3$-bp insertion, $\mathrm{h}=6$-bp insertion, $\mathrm{j}=1$-bp deletion, and $1=6$-bp insertion (see Table 1). For indels, arrows symbolize synapomorphies and bars indicate autapomorphies. Numbers above branches are bootstrap values $>50 \%$ and numbers below branches are decay indices. 


\section{RESTIO}

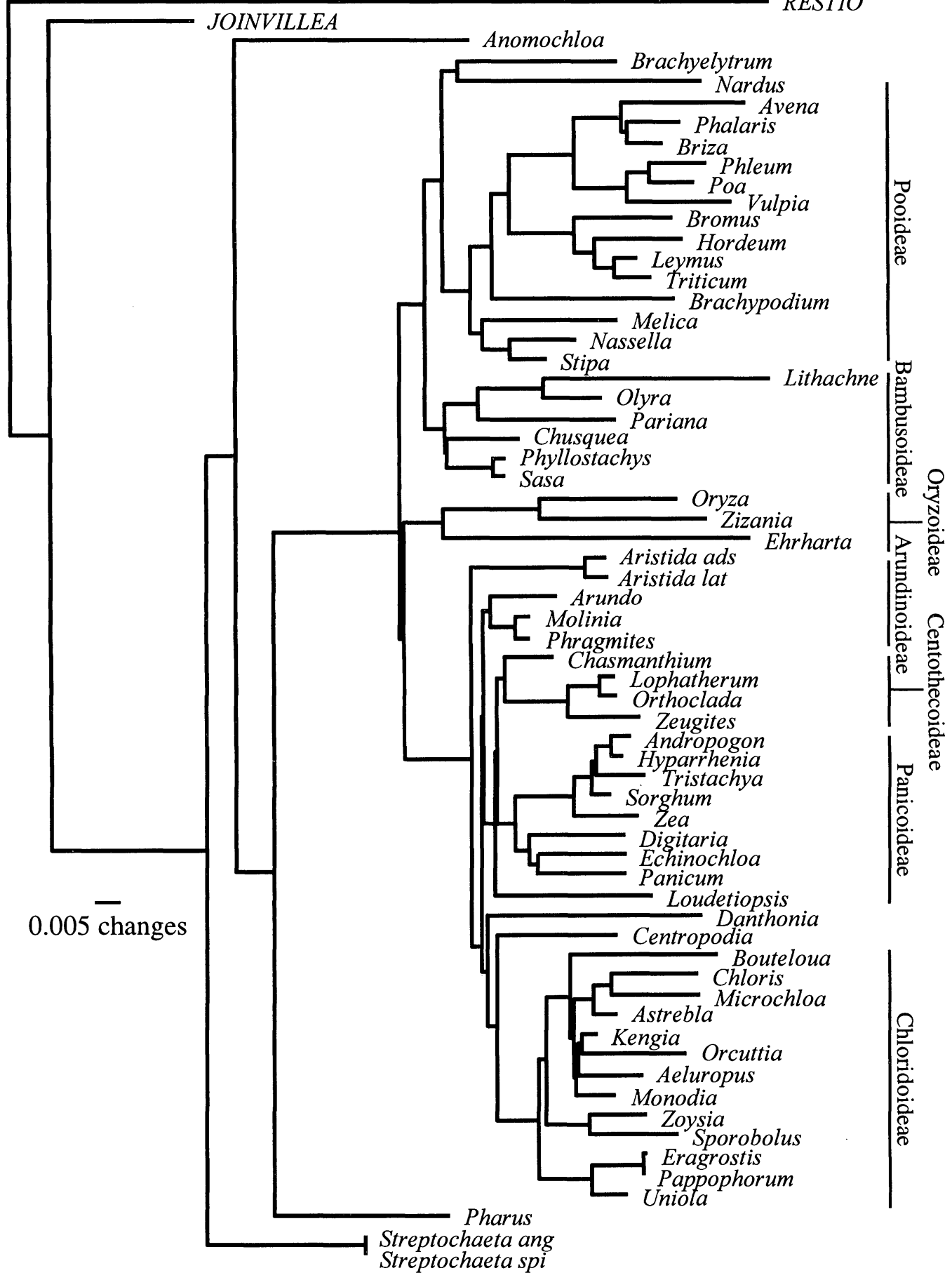

Figure 3. Neighbor-Joining phylogram based on Juke-Cantor and Kimura 2-parameter distance models. For abbreviations of species, see Figure 2 caption. 
Pharus that corresponded to: (1) Bambusoideae, Oryzoideae, and Pooideae; and (2) PACC. This split led them to coin the term BOP for the first group, although the clade was weakly supported. Mathews and Sharrock (1996) reported a similar bifurcation based on 174 informative sites from combined phytochrome gene sequence data. However, the Bambusoideae and Oryzoideae were represented only by Bambusa and Oryza, respectively.

The appearance of subfamilies Panicoideae, Arundinoideae, Centothecoideae, and Chloridoideae in one major group was first demonstrated by Hilu and Wright (1982) on the basis of a phenetic analysis of morphological-anatomical characters. Further support for this grouping was provided by the protein and immunological studies of Hilu and Esen (1988) and Esen and Hilu (1989). This assemblage, which they named PACC, was also evident in the cpDNA restriction site study of Davis and Soreng (1993). The monophyly of the group has since been substantiated by overwhelming molecular and structural data (Davis \& Soreng, 1993; Barker et al., 1995; Clark et al., 1995; Duvall \& Morton, 1996; Liang \& Hilu, 1996; Soreng \& Davis, 1998; Hsiao et al., 1999). Additional support for the monophyly of the PACC group is evident from the 6-bp insertion at the $3^{\prime}$ end of mat $\mathrm{K}$ that is lacking in other grasses and outside the Poaceae (Hilu \& Alice, in press a).

The mat $\mathrm{K}$ data also show a bifurcation in the evolution of the Poaceae. Following the sequential divergence of Streptochaeta, Anomochloa, and Pharus, the Bambusoideae and Pooideae form a clade supported by an $88 \%$ bootstrap and decay of 4 , and the Oryzoideae appear sister to PACC. Support for the latter relationship is very low $(<50 \%$ bootstrap and decay of 1). Therefore, the BOP clade does not gain support from this study, nor is it strongly contradicted. However, the sister-group relationship between Pooideae and PACC is not substantiated by these matK data. In contrast with the well-defined monophyletic PACC lineage, available evidence is inconclusive concerning the phylogenetic affinities among the Bambusoideae, Pooideae, and Oryzoideae.

\section{SYSTEMATICS OF GRASS SUBFAMILIES}

Bambusoideae. The emergence of Streptochaeta, Anomochloa, and Pharus as basal lineages in the mat $\mathrm{K}$ phylogeny provides further evidence for the polyphyly of the Bambusoideae as previously suspected by Kellogg and Watson (1993) and demonstrated by other researchers (Barker et al., 1995; Clark et al., 1995; Duvall \& Morton, 1996; Soreng
\& Davis, 1998; Hsiao et al., 1999). The clade containing Bambusoideae (excluding Brachyelytrum) shows strong support for the monophyly of the herbaceous genera (98\% bootstrap and 7 decay). Within this clade the olyroid genera, Olyra and Lithachne, form a well-supported lineage sister to Pariana (Parianeae). However, the woody bambusoids (Bambuseae) do not segregate into their respective subtribes sensu Clayton and Renvoize (1986). Sasa and Chusquea of the Arundinariinae do not appear monophyletic; instead, Sasa forms a strongly supported clade with Phyllostachys (Bambusinae), and Chusquea is unresolved. The lack of support for the monophyly of these two subtribes is also apparent in other studies (Clark et al., 1995; Soreng \& Davis, 1998; Hsiao et al., 1999). These studies also indicate a position for Brachyelytrum at or near the base of the Pooideae clade.

Pooideae. The Pooideae clade (excluding Nardus) has good support and includes the Stipeae that emerge as a basal lineage along with the unresolved Melica (Meliceae). The Stipeae have been inconsistently treated in the Bambusoideae, Pooideae, Arundinoideae, and as a distinct subfamily with affiliation to the Bambusoideae (discussed in Barkworth \& Everett, 1987). The basal or near-basal position of the Stipeae in the Pooideae is in agreement with other molecular data (Barker et al., 1995; Clark et al., 1995; Mathews \& Sharrock, 1996; Catalán et al., 1997; Soreng \& Davis, 1998).

The remaining pooid genera form two major lineages with Brachypodium as the sister taxon. The Triticeae and Bromeae form one subclade, and the Aveneae and Poeae comprise the other. This phylogenetic position for Brachypodium is in agreement with Catalán et al.'s (1997) results and does not differ greatly from that in Soreng and Davis (1998) where the genus was sister to the Meliceae and basal to most of the Pooideae. Brachypodium has been placed in the Triticeae, Bromeae, and Brachypodieae (Bor, 1970; Harz, 1980; Hilu \& Wright, 1982; Clayton \& Renvoize, 1986; Macfarlane, 1987). The taxonomic uncertainties regarding Brachypodium are due to its floret characteristics that are intermediate between the Triticeae and Bromeae, possession of smaller chromosomes than those found in the Triticeae, and occurrence of base chromosome numbers of 7,9 , and 10 (see Hilu \& Wright, 1982). The matK-based phylogeny herein supports the tribal rank of Brachypodium.

The position of Bromus as sister to the Triticeae underscores the phylogenetic affinities between these taxa. Bromus is generally placed in its own tribe, and Clayton (1978) considered it a link between the Poeae and Triticeae. The sister relation- 
ship between the Bromeae and Triticeae is congruent with the study of Soreng and Davis (1998) and Catalán et al. (1997). The three genera of Triticeae sampled seem monophyletic, and Leymus and Triticum appear more closely related to each other than either is to Hordeum, as evidenced by a synapomorphic 3-bp insertion (Table 1, Fig. 2). The remaining six pooid genera form two lineages: (1) the Poa-Vulpia-Phleum clade, and (2) the Avena-Phalaris-Briza clade. Poa and Vulpia belong to the Poeae and Avena and Phalaris to the Aveneae (Clayton \& Renvoize, 1986). The positions of Briza (Poeae) and Phleum (Aveneae) in this analysis are anomalous. Yet, other studies that have included Briza (Soreng et al., 1990; Hsiao et al., 1999) resolve it within the Aveneae.

The placement of Melica as an unresolved lineage at or near the base of the Pooideae is congruent with other molecular phylogenies and supports its treatment as a separate tribe. In the NJ tree, Melica is sister to the Stipeae (Fig. 3). Brachyelytrum, traditionally classified in the Bambusoideae, emerges in a clade with Nardus (Pooideae; Nardeae) as sister group to the remaining Pooideae. Although this relationship may be inconsistent with traditional classifications based largely on morphology, it is in close agreement with recent phylogenetic studies (Clark et al., 1995; Catalán et al., 1997; Soreng \& Davis, 1998; Hsiao et al., 1999). Each of these studies presents alternative relationships for $\mathrm{Bra}$ chyelytrum and Nardus, but all indicate that one or both genera are basal in an expanded definition of Pooideae. The overall morphological and anatomical affinity between Nardus and the Pooideae has been demonstrated by Hilu and Wright (1982). Clayton and Renvoize (1986) asserted that the unusual spikelet of the Nardeae gives no clue to its origin, but proposed that it would be better treated as an early departure from the pooid line before the loss of microhairs. The taxa identified as basal to the Pooideae could fit Clayton and Renvoize's notion of odd genera in an evolutionary transition. A number of them have one floret per spikelet, a mixture of pooid and non-pooid characters, and currently appear as relics having different geographic distributions. This information may point to an early evolution of a pre-pooid group and considerable subsequent diversification and geographic radiation.

Oryzoideae. The association of Ehrharta (Ehrharteae) with the Oryzoideae (bootstrap 100\% and decay index 10, Fig. 2) provides strong evidence for an expanded concept of this subfamily. Historically, the taxonomic position of Ehrharta (Ehrharteae) has been disputed. The taxon has been placed within the Bambusoideae (Renvoize, 1986; Watson \& Dallwitz, 1992), Arundinoideae (Ellis, 1987), and Oryzoideae (see Hilu \& Wright, 1982). In a review of the Ehrharteae, Tateoka (1963) concluded that the tribe could be placed in or near the Oryzoideae or near the "arundiform" grasses. An arundinoid affinity of the Ehrharteae is dismissed because of its lack of a 6-bp deletion synapomorphic to the PACC clade that includes this subfamily (Hilu \& Alice, in press a). An oryzoid alliance of Ehrharta was evident in the numerical analysis of Hilu and Wright (1982). In contrast, Soreng and Davis's (1998) cladistic analysis of structural characters does not support the inclusion of Ehrharta in the Oryzoideae. The strong support for the $E h r-$ harta-Oryza-Zizania clade using matK sequences clearly demonstrates the phylogenetic affinity of Ehrharta to the oryzoid grasses. This phylogenetic position for Ehrharta is in agreement with the $n d h \mathrm{~F}$-based phylogeny of Clark et al. (1995), the combined cpDNA restriction site and structural data analysis of Soreng and Davis (1998), and the ITS-based phylogeny of Hsiao et al. (1999).

The sister relationship of the oryzoid lineage to the PACC clade in this mat $\mathrm{K}$ parsimony tree (Fig. 2 ) is not congruent with studies using other data. Those studies have variably placed the Oryzoideae in an unresolved trichotomy with the Bambusoideae and Pooideae (Clark et al., 1995), sister to the Bambusoideae (Barker et al., 1995; Hsiao et al., 1999), or elsewhere (Duvall \& Morton, 1996; Mathews \& Sharrock, 1996; Soreng \& Davis, 1998). However, this sister position of the oryzoids to PACC is not well supported (bootstrap $<50 \%$ and decay index 1), and the bootstrap 50\% majorityrule tree shows subfamily Oryzoideae sister to the bambusoid-pooid clade. Differential weighting of the codon positions also places the oryzoids in a trichotomy with PACC and bambusoid + pooid lineages (tree not shown).

The oryzoid grasses have either been recognized as a distinct subfamily or included in the Bambusoideae. Analyses of structural data have been inconsistent in terms of taxonomic rank of the oryzoids (Hilu \& Wright, 1982; Baum, 1987; Campbell \& Kellogg, 1987; Kellogg \& Watson, 1993; Soreng \& Davis, 1998). The presence of 10-18 kDa (kilodalton) prolamins endorses the affinities between oryzoid and bambusoid taxa (Hilu \& Esen, 1988), but the low immunological cross-reactivities clearly demonstrate a high divergence (Esen \& Hilu, 1989). DNA data have shown the oryzoids as a distinct entity (Hamby \& Zimmer, 1988; Duvall \& Morton, 1996; Barker et al., 1995, NJ tree; Clark et al., 1995; Soreng \& Davis, 1998). In this study, 
the monophyletic oryzoid clade (including Ehrhar$t a$ ) is strongly supported by a $94 \%$ bootstrap and a decay index of 10 . This molecular information thus strongly supports the treatment of the Oryzoideae as a distinct subfamily, although its phylogenetic position is unclear.

Aristideae. This tribe is represented only by Aristida in this study. The basal position of the genus in the PACC clade is weakly supported (bootstrap $<50 \%$ and decay index 1). The taxonomic position of the Aristideae in the Poaceae is disputable because of unique anatomical features. The tribe has been placed either in the Chloridoideae or Arundinoideae (reviewed in Hilu \& Wright, 1982). Caroline and Jacobs (cf. Jacobs, 1987) found differing differentiation for the two Kranz sheaths in Aristida species from different ecological habitats, leading Jacobs (1987) to believe that Aristida is not distantly related to the chloridoid grasses. Based on prolamin polypeptide size and immunological similarities, Aristida appeared intermediate between the Chloridoideae and Arundinoideae (Hilu \& Esen, 1990, 1993; Esen \& Hilu, 1991). The prolamin profile of Stipagrostis differs from that of Aristida, and the former shows low immunological affinities to Aristida, grouping with the Chloridoideae (Esen \& Hilu, 1991). Sequence data from $r b c \mathrm{~L}$ show Aristida and Stipagrostis to be monophyletic and sister to the Chloridoideae (Barker et al., 1995). The chloridoid affinity of Aristida was also apparent in the $n d h \mathrm{~F}$-based phylogeny (Clark et al., 1995). Although the distinctness of Aristida in the PACC clade is not in question, the phylogenetic position of the Aristideae remains unsettled, especially given that the tribe has been represented by only the type genus in the majority of recent studies. Good representation of the tribe and increased resolution are essential before a conclusive assessment of its taxonomic status and phylogenetic position can be determined. The group represents a heterogeneous assemblage particularly from anatomical and physiological perspectives; Stipagrostis has a Kranz anatomy that differs from the unique Kranz pattern of Aristida; Sartidia lacks Kranz anatomy.

Panicoideae. The Panicoideae do not appear monophyletic in our study because the position of Loudetiopsis (Arundinelleae) is unresolved in the parsimony tree (Fig. 2) and is sister to the Centothecoideae-Panicoideae in the NJ tree (Fig. 3). However, the remaining eight genera sampled do form a strongly supported clade divided into two lineages: one corresponding to the Paniceae (Digitaria, Echinochloa, and Panicum); and the other representing an apparently paraphyletic Andropo- goneae due to the inclusion of Tristachya (Arundinelleae). Support for the monophyly of the Panicoideae, excluding Loudetiopsis, is very convincing ( $95 \%$ bootstrap and a decay index of 4). Similar results were evident in Clark et al.'s (1995) study that showed Danthoniopsis (Arundinelleae) nested in a clade comprised of Centothecoideae + Thysanolaena (Thysanolaeneae; Arundinoideae). This clade was sister to the Pancoideae.

Tristachya (Arundinelleae) is strongly nested (100\% bootstrap and 14 decay) within the Andropogoneae clade of Zea, Sorghum, Andropogon, and Hyparrhenia (Fig. 2). The presence of spikelets in triads characteristic of the Arundinelleae breaks down in Tristachya, where paired spikelets of the andropogonoid type are found in some species. Tristachya also emerged within the Andropogoneae in the $r b c \mathrm{~L}$ and $r p o \mathrm{C} 2$ (data set II) studies of Barker et al. (1995, 1999). Hsiao et al.'s (1999) ITS phylogeny is the only other study that included an Arundinelleae representative. In their analysis, Arundinella was sister to the Andropogoneae. Thus, it seems that the Arundinelleae are not a monophyletic tribe, but perhaps distributed among at least three lineages. This postulate gains support from the molecular study of Mason-Gamer et al. (1998) in which the Arundinelleae were not monophyletic. The Arundinelleae share some spikelet features with the Andropogoneae and are thought to have given rise to the latter tribe (Clayton, 1981). The alliance of Tristachya with the Andropogoneae is supported by this matK study but not its ancestral position.

Centothecoideae. The Centothecoideae were segregated from the Arundinoideae by Clayton (1978); however, their phylogenetic position remains unresolved. Based on the $r b c \mathrm{~L}$ study of Barker et al. (1995), the centothecoid Chasmanthium occurred in a clade with Thysanolaena (Arundinoideae; Thysanolaeneae) and was separated from the Panicoideae by the arundinoid Gynerium. However, the position of Gynerium was described as "equivocal." In the $n d h \mathrm{~F}$ study of Clark et al. (1995), the centothecoid genera Zeugites and Chasmanthium appeared in a clade containing Danthoniopsis (Panicoideae; Arundinelleae) and Thysanolaena. In this matK study, the Centothecoideae appear monophyletic and related to the Panicoideae, although support is low and neither Danthoniopsis nor Thysanolaena were sampled. Apart from Chasmanthium, the remaining Centothecoideae (Zeugites, Lophatherum, and Orthoclada) are very closely related (Fig. 2; 100\% bootstrap and decay 15), raising the question about the position of Chasmanthium. The centothecoids cannot be included in the Bambusoideae as treated by Watson and 
Dallwitz (1992) because they possess the 6-bp insertion unique to PACC (Hilu \& Alice, in press a), and based on their phylogenetic position in this and other molecular studies. A more comprehensive sampling of the Centothecoideae, including potentially related genera such as Danthoniopsis, Gynerium, and Thysanolaena, are important prerequisites for accurately assessing the monophyly of this group and its relationships within PACC. Nevertheless, the studies that have included centothecoid representatives, including this one, demonstrate a greater alliance with the Panicoideae than with either the Arundinoideae or Chloridoideae.

Arundinoideae. The Arundinoideae are known to be a taxonomically problematic group. The polyphyletic or paraphyletic nature of the arundinoid grasses has been proposed on the basis of morphoanatomical characters (Campbell \& Kellogg, 1987) and $r b c \mathrm{~L}$, rpoC2, and $n d h \mathrm{~F}$ sequence data (Barker et al., 1995, 1999; Clark et al., 1995). The Arundinoideae sample in Barker et al. $(1995,1999)$ is one of the largest among these studies. They presented one of 26 most-parsimonious trees that showed the arundinoids split between two major clades that are supported by bootstrap values of only $33 \%$ and $47 \%$. The number of most parsimonious trees and the low bootstrap values make it difficult to assess the relationships of the arundinoid taxa. A more recent study based on the $r b c \mathrm{~L}$ gene (Duvall \& Morton, 1996) implied monophyly of the arundinoids; however, the study included only Arundo and Phragmites.

Our study does not substantiate a monophyletic Arundinoideae. The positions of Arundo and Molinia + Phragmites are unresolved, whereas Danthonia and Centropodia are closely related to the Chloridoideae. The Phragmites-Molinia clade is strongly supported with a $98 \%$ bootstrap and a decay index of 5 (Fig. 2). The affinity between Molinia and Phragmites is apparent in Clayton and Renvoize's (1986: fig. 14) diagram of relationships of the Arundineae and is congruent with the results of Barker et al. (1995, 1999; used syn. Moliniopsis) and the combined analysis of Soreng and Davis (1998).

Chloridoideae. The monophyly of the Chloridoideae, which is often disputed, is strongly supported by these $m a t \mathrm{~K}$ sequence data (Fig. 2) and a more comprehensive matK study (Hilu \& Alice, in press b). The association of Centropodia and Danthonia with the chloridoid clade is quite intriguing. The sister relationship of Centropodia to the Chloridoideae is in agreement with the $r b c \mathrm{~L}$-based phylogeny of Barker et al. (1995), as is the position of Danthonia. Centropodia is traditionally placed in the Arundineae (Clayton \& Renvoize, 1986) or considered as a danthonoid (see Barker et al., 1995). The genus has a well-developed Kranz anatomy (Ellis, 1984) that separates it from the Arundineae and allies it with the Chloridoideae. Barker et al. (1995) indicated that the lack of haustorial synergids supports its exclusion from the danthonoid grasses. The multinerved glumes and lemmas of Centropodia represent traits shared with the Pappophoreae and Uniolinae, members of a basal chloridoid lineage.

The major tribes Eragrostideae and Chlorideae do not appear to be monophyletic. The lack of support for the Chlorideae and Eragrostideae as distinct lineages was also reflected in the morphological-anatomical study of the subfamily (Van den Borre \& Watson, 1997) and the matK-based study of Hilu and Alice (in press b). The emergence of the Pappophoreae, Uniolinae, and Eragrostis in a basal clade is congruent with Hilu and Alice (in press b). Clayton and Renvoize (1986) placed the Uniolinae as a basal group in the Chloridoideae, and Van den Borre and Watson (1997) demonstrated a near-basal position of the Pappophoreae in their phylogeny.

Another noteworthy group includes Sporobolus and Zoysia in a well-supported clade that is consistent with Soreng and Davis (1998) and Clark et al. (1995). The presence of the Chlorideae genera Astrebla, Chloris, and Microchloa in a strongly supported clade is taxonomically sound. A similar assemblage was also apparent in Van den Borre and Watson's (1997) morphological study. A comprehensive systematic study of the Chloridoideae is in progress (K. Hilu \& L. Alice, unpublished data).

The mat $\mathrm{K}$ gene provides sequence information sufficient for elucidating evolutionary relationships among grass lineages. The results of this study identify several well-supported clades that are in agreement with other recent molecular studies. Most evidence points to Streptochaeta and Anomochloa as representing the most basal grass lineages. However, the question of whether these two genera constitute a monophyletic subfamily or two distinct lineages remains unanswered due to conflict among data sets. Pharus has an intriguing position. Although Pharus corresponds with Streptochaeta and Anomochloa by its own distinct lineage, the genus is strongly separated from most other grasses supporting its subfamilial status as proposed by Clark and Judziewicz (1996). Yet, Pharus shares with other grasses the synapomorphic 1-bp deletion that is not found in Streptochaeta and Anomochloa (Hilu \& Alice, in press a). Subfamilies 
Bambusoideae, Oryzoideae, and Pooideae can be considered monophyletic with individual modification. As others have demonstrated, the Bambusoideae should exclude Streptochaeta, Anomochloa, Pharus, and possibly Brachyelytrum, the last mentioned being allied with Nardus and other Pooideae. Oryzoid taxa, including Ehrharta, resolve well from the Bambusoideae and are strongly supported as a monophyletic unit deserving subfamilial rank. The Pooideae are also well supported with their definition expanded to include Brachyelytrum. Based on existing phylogenetic evidence, there is no consensus with regard to the relationships among Bambusoideae, Oryzoideae, and Pooideae or to their affinities with the firmly established PACC clade.

Within PACC, the best supported subfamily is the Chloridoideae. The Panicoideae (excluding Loudetiopsis) and the Centothecoideae are also taxonomically sound groups, although support is low for the relationship between Chasmanthium and other centothecoid members. However, the Centothecoideae may be paraphyletic due to the inclusion of such genera as Danthoniopsis, Gynerium, and Thysanolaena nesting within the centothecoid clades in other studies. Finally, the Arundinoideae are clearly polyphyletic with some elements at or near the base of the PACC clade (Aristida), and others (Danthonia and Centropodia) closely related to the Chloridoideae.

Most molecular phylogenies of the Poaceae have been inferred from chloroplast genome data and, thus, may not be considered truly independent. To further resolve the systematic relationships in $\mathrm{Po}-$ aceae and to test existing hypotheses, robust, nuclear-based phylogenetic analyses are warranted.

\section{Literature Cited}

Barker, N. P., H. P. Linder \& E. H. Harley. 1995. Polyphyly of Arundinoideae (Poaceae): Evidence from $r b c \mathrm{~L}$ sequence data. Syst. Bot. 20: 423-435.

$\longrightarrow, 1$. 1999. Sequences of the grassspecific insert in the rpoC2 gene elucidate generic relationships of the Arundinoideae (Poaceae). Syst. Bot. 23: 327-350.

Barkworth, M. E. \& J. Everett. 1987. Evolution in the Stipeae: Identification and relationships of its monophyletic taxa. Pp. 251-264 in T. R. Soderstrom, K. W. Hilu, C. S. Campbell \& M. A. Barkworth (editors), Grass Systematics and Evolution. Smithsonian Institution Press, Washington, D.C.

Baum, B. R. 1987. Numerical taxonomic analyses of the Poaceae. Pp. 334-342 in T. R. Soderstrom, K. W. Hilu, C. S. Campbell \& M. A. Barkworth (editors), Grass Systematics and Evolution. Smithsonian Institution Press, Washington, D.C.

Bew, E. A. 1929. The World's Grass: Their Differentiation, Distribution, Economics and Ecology. Longmans, Green, London, New York.
Bor, N. L. 1970. Gramineae. In: K. H. Rechinger (editor), Flora Iranica, No. 70. Akademische Druck M. Verlagsanstalt, Graz.

Borre, A. Van den \& L. Watson. 1997. On the classification of the Chloridoideae (Poaceae). Austral. Syst. Bot. 10: 491-531.

Bremer, K. 1988. The limits of amino acid sequence data in angiosperm phylogenetic reconstruction. Evolution 42: 795-803.

Campbell, C. S. \& E. A. Kellogg. 1987. Sister group relationships of the Poaceae. Pp. 217-224 in T. R. Soderstrom, K. W. Hilu, C. S. Campbell \& M. A. Barkworth (editors), Grass Systematics and Evolution. Smithsonian Institution Press, Washington, D.C.

Catalán, P., E. A. Kellogg \& R. G. Olmstead. 1997. Phylogeny of Poaceae subfamily Pooideae based on chloroplast $n d h \mathrm{~F}$ gene sequences. Molec. Phylogenetics Evol. 8: 150-166.

Clark, L. G., W. Zhang \& J. F. Wendel. 1995. A phylogeny of the grass family (Poaceae) based on $n d h \mathrm{~F}$ sequence data. Syst. Bot. 20: 436-460.

\& E. J. Judziewicz. 1996. The grass subfamilies Anomochlooideae and Pharoideae (Poaceae). Taxon 45: 641-645.

Clayton, W. D. 1978. Gramineae. Pp. 285-290 in V. H. Heywood (editor), Flowering Plants of the World. Mayflower Books, New York.

- 1981. Evolution and distribution of grasses. Ann. Missouri Bot. Gard. 68: 5-25.

— \& S. A. Renvoize. 1986. Genera Graminum. HMSO Publications, London.

Cummings, M. P., L. M. King \& E. A. Kellogg. 1994. Slipped-strand mispairing in plastid gene: rpoC2 in grasses (Poaceae). Molec. Biol. Evol. 11: 1-8.

Davis, J. I. \& R. J. Soreng. 1993. Phylogenetic structure in the grass family (Poaceae) as inferred from chloroplast DNA restriction site variation. Amer. J. Bot. 80: 1444-1454.

Doebley, J., M. Durbin, E. M. Golenberg, M. T. Clegg \& D. P. Ma. 1990. Evolutionary analysis of the large subunit of carboxylase $(r b c \mathrm{~L})$ nucleotide sequence among the grasses (Gramineae). Evolution 44: 1097-1108.

Donoghue, M. J., R. G. Olmstead, J. F. Smith \& J. D. Palmer. 1992. Phylogenetic relationships of Dipsacales based on $r b c \mathrm{~L}$ sequences. Ann. Missouri Bot. Gard. 79: 333-345.

Doyle, J. J., J. I. Davis, R. J. Soreng, D. Garvin \& M. J. Anderson. 1992. Chloroplast DNA inversions and the origin of the grass family (Poaceae). Proc. Natl. Acad. U.S.A. 89: 7722-7726.

Duvall, M. R. \& B. R. Morton. 1996. Molecular phylogenetics of Poaceae: An expanded analysis of $r b c \mathrm{~L}$ sequence data. Molec. Phylogenetics Evol. 5: 352-358.

Ellis, R. P. 1984. Leaf anatomy of the South African Danthonieae (Poaceae). IX Asthenatherum glaucum. Bothalia 15: 153-159.

1987. A review of comparative leaf blade anatomy in the systematics of the Poaceae: The past twentyfive years. Pp. 3-10 in T. R. Soderstrom, K. W. Hilu, C. S. Campbell \& M. A. Barkworth (editors), Grass Systematics and Evolution. Smithsonian Institution Press, Washington, D.C.

Ems, S. C., C. W. Morden, C. K. Dixon, K. H. Wolfe, C. W. Depamphilis \& J. D. Palmer. 1995. Transcription, splicing and editing of plastid RNAs in the nonphotosynthetic plant Epifagus virginiana. Pl. Molec. Biol. 29: 721-733. 
Eriksson, T. \& Wikstrom, N. 1996. AutoDecay 3.0. Stockholm University, Stockholm.

Esen, A. \& K. W. Hilu. 1989. Immunological affinities among subfamilies of the Poaceae. Amer. J. Bot. 76: 196-203.

- - 1991. Electrophoretic and immunological studies of prolamins in the Poaceae. II. Phylogenetic affinities of the Aristideae. Taxon 40: 5-17.

Felsenstein, J. 1985. Confidence limits on phylogenies: An approach using the bootstrap. Evolution 39: 783791.

Hamby, R. K. \& E. A. Zimmer. 1988. Ribosomal RNA sequences for inferring phylogeny within the grass family (Poaceae). Pl. Syst. Evol. 160: 29-37.

Harz, C. O. 1980. Beitrage zur Systematik der Gramineen. Linnaea 43: 1-48.

Hillis, D. M. \& J. P. Huelsenbeck. 1992. Signal, noise and reliability in molecular phylogenetic analyses. J. Heredity 83: 189-195.

Hilu, K. W. \& L. A. Alice. In press a. Evolutionary implications of matK indels in Poaceae. Amer. J. Bot. \& - In press b. Phylogenetic relationships in subfamily Chloridoideae (Poaceae) based on mat $\mathrm{K}$ sequences: A preliminary assessment. In S. W. L. Jacobs \& J. Everett (editors), Grass Systematics and Evolution, Vol. 2 of Proceedings, 2nd International Conference on the Comparative Biology of Monocotyledons, Sydney, Australia, 1998.

\& A. Esen. 1988. Prolamin size diversity in the Poaceae. Biochem. Syst. \& Ecol. 16: 457-465.

— — 1990. Prolamin and immunological studies in Poaceae. I. Subfamily Arundinoideae. Pl. Syst. Evol. 173: 57-70.

— \& 1993. Prolamin and immunological studies in the Poaceae: III. Subfamily Chloridoideae. Amer. J. Bot. 80: 104-113.

\& H. Liang. 1997. The matK gene: Sequence variation and application in plant systematics. Amer. J. Bot. 84: 830-839.

\& K. Wright. 1982. Systematics of Gramineae: A cluster analysis study. Taxon 31: 9-36.

Holmgren, P. K., N. H. Holmgren \& L. C. Barnett (Editors). 1990. Index Herbariorum. Part 1, The Herbaria of the World, 8th ed. Regnum Veg. 120, New York Botanical Garden, New York.

Hsiao, C., N. J. Chatterton, K. H. Asay \& K. B. Jensen. 1994. Phylogenetic relationships of 10 grass species: An assessment of phylogenetic utility of the internal transcribed spacer region in nuclear ribosomal DNA in monocots. Genome 37: 112-120.

, S. W. L. Jacobs, N. J. Chatterton \& K. H. Asay. 1999. A molecular phylogeny of the grass family (Poaceae) based on the sequences of nuclear ribosomal DNA (ITS). Austral. Syst. Bot. 11: 667-688.

Hubbard, C. E. 1948. Gramineae. In: J. Hutchinson (editor), British Flowering Plants. P. R. Gawthorn, London.

Jacobs, S. W. L. 1987. Systematics of the chloridoid grasses. Pp. 310-322 in T. R. Soderstrom, K. W. Hilu, C. S. Campbell \& M. A. Barkworkth (editors), Grass Systematics and Evolution. Smithsonian Institution Press, Washington, D.C.

Johnson, L. A. \& D. E. Soltis. 1994. matK DNA sequences and phylogenetic reconstruction in Saxifragaceae s. str. Syst. Bot. 19: 143-156.

— \& 1995. Phylogenetic inference in Saxifragaceae sensu stricto and Gilia (Polemoniaceae) us- ing matK sequences. Ann. Missouri Bot. Gard. 82: 149-175.

Jukes, T. H. \& C. R. Cantor. 1969. Evolution of protein molecules. Pp. 2l-23 in H. N. Munro (editor), Mammalian Protein Metabolism. Academic Press, New York.

Kellogg, E. A. \& C. S. Campbell. 1987. Phylogenetic analysis of the Gramineae. Pp. 310-322 in T. R. Soderstrom, K. W. Hilu, C. S. Campbell \& M. A. Barkworth (editors), Grass Systematics and Evolution. Smithsonian Institution Press, Washington, D.C.

\& H. P. Linder. 1995. Phylogeny of Poales. Pp. 511-542 in P. J. Rudall, P. J. Cribb, D. F. Cutler \& C. J. Humphries (editors), Monocotyledons: Systematics and Evolution, Vol. 2. Royal Botanic Gardens, Kew.

\& L L. Watson. 1993. Phylogenetic studies of a large data set. I. Bambusoideae, Andropogonoeae, and Pooideae (Gramineae). Bot. Rev. 59: 273-320.

Kimura, M. 1980. A simple method for estimating evolutionary rates of base substitutions through comparative studies of nucleotide sequences. J. Molec. Evol. 16: $111-120$.

Kron, K. A. 1997. Phylogenetic relationships of Rhododendroideae (Ericaceae). Amer. J. Bot. 84: 973-980.

Liang, H. \& K. W. Hilu. 1996. Application of the matK gene sequences to grass systematics. Canad. J. Bot. 74: 125-134.

Macfarlane, T. D. 1987. Poaceae subfamily Pooideae. Pp. 265-276 in T. R. Soderstrom, K. W. Hilu, C. S. Campbell \& M. A. Barkworth (editors), Grass Systematics and Evolution. Smithsonian Institution Press, Washington, D.C.

Maddison, W. P. \& D. R. Maddison. 1992. MacClade, version 3.01. Sinauer, Sunderland, Massachusetts.

Mason-Gamer, R. J., C. F. Weil \& E. A. Kellogg. 1998. Granule-bound starch synthase: Structure, function and phylogenetic utility. Molec. Biol. Evol. 15: 1658-1673.

Mathews, S. \& R. A. Sharrock. 1996. The phytochrome gene family in grasses (Poaceae): A phylogeny and evidence that grasses have a subset of the loci found in dicot angiosperms. Molec. Biol. Evol. 13: 1141-1150.

M'Ribu, K. \& K. W. Hilu. 1996. Application of random amplified polymorphic DNA to study genetic diversity in Paspalum scrobiculatum L. (Kodo millet, Poaceae). Genetic Res. Crop Evol. 43: 203-210.

Nadot, S., R. Bajon \& B. Lejeune. 1994. The chloroplast gene rps 4 as a tool for the study of Poaceae phylogeny. Pl. Syst. Evol. 191: 27-38.

Neuhaus, H. \& G. Link. 1987. The chloroplast tRNALYS(UUU) gene from mustard (Sinapis alba) contains a class II intron potentially coding for a maturaserelated polypeptide. Curr. Genet. 11: 251-257.

Olmstead, R. G. \& J. D. Palmer. 1994. Chloroplast DNA systematics: A review of methods and data analysis. Amer. J. Bot. 81: 1205-1224.

Prat, H. 1960. Vers une classification naturelle des Graminées. Bull. Soc. Bot. France 107: 32-79.

Renvoize, S. A. 1986. A survey of leaf-blade anatomy in grasses: VIII. Arundinoideae. Kew Bull. 41: 323-342.

Sanderson, M. J. \& M. J. Donoghue. 1989. Patterns of variation in levels of homoplasy. Evolution 43: 17811795.

Soderstrom, T. R. 1981. Some evolutionary trends in the Bambusoideae (Poaceae). Ann. Missouri Bot. Gard. 68: 15-47.

Soreng, R. J. \& J. I. Davis. 1998. Phylogenetics and character evolution in the grass family (Poaceae): Simulta- 
neous analysis of morphological and chloroplast DNA restriction site characters sets. Bot. Rev. 64: 1-85.

- \& J. J. Doyle. 1990. A phylogenetic analysis of chloroplast DNA restriction site variation in Poaceae subfamily Pooideae. Pl. Syst. Evol. 172: 8397.

Stebbins, G. L. 1956. Cytogenetics and evolution of the grass family. Amer. J. Bot. 43: 890-905.

1982. Major trends of evolution in the Poaceae and their possible significance. Pp. 3-36 in J. R. Estes, R. J. Tyrl \& J. N. Brunken (editors), Grasses and Grasslands: Systematics and Ecology. Univ. Oklahoma Press, Norman.
Swofford, D. L. 1998. PAUP: Phylogenetic Analysis Using Parsimony. Version 4.0b2a. Sinauer, Sunderland, Massachusetts.

Tateoka, T. 1963. Notes on some grasses. XIII. Relationship between Oryzeae and Ehrharteae, with special reference to leaf anatomy and histology. Bot. Gaz. 124: 264-270.

Tsvelev, N. N. 1983. Grasses of the Soviet Union. Part I. Translated by B. R. Sharma, Amerind, New Delhi.

Watson, L. \& M. J. Dallwitz. 1992. The Grass Genera of the World. C. A. B. International, Univ. Press, Cambridge. 
Appendix 1. Accessions used along with their classification, which generally follows Clayton and Renvoize (1986), and sources of material. Subfamilial classification of Anomochloa, Pharus, and Streptochaeta follows Clark and Judziewicz (1996). Cultivars are indicated by quotation marks following species' names. BBG = University of Bonn Botanical Garden, MBG = Missouri Botanical Garden living collections, NIAR = National Institute of Agrobiological Resources, PBG = Pretoria Botanical Gardens, VTDPP = Virginia Tech Department of Plant Pathology. PI and W6 numbers = U.S. Department of Agriculture-National Plant Germplasm System accessions. Herbarium codes follow Holmgren et al. (1990). * = accession of Brachypodium sylvaticum either PI 325218 (ex USSR) or PI 268222 (Iran).

\begin{tabular}{|c|c|c|c|}
\hline Taxon & Origin & Source/Voucher & GenBank \\
\hline \multicolumn{4}{|l|}{ RESTIONACEAE } \\
\hline Restio tetraphyllus Labill. & unknown & BBG 00700-90/T. Borsch 3319, VPI & AF164379 \\
\hline \multicolumn{4}{|l|}{ JOINVILLEACEAE } \\
\hline Joinvillea ascendens Gaud. ex Brongn. \& Gris. & unknown & J. Davis s.n. $(\mathrm{DNA}) / H$. Moore $10438, \mathrm{BH}$ & AF 164380 \\
\hline \multicolumn{4}{|l|}{ POACEAE } \\
\hline \multicolumn{4}{|l|}{ Anomochlooideae } \\
\hline \multicolumn{4}{|l|}{ Anomochloeae } \\
\hline Anomochloa marantoidea Brongn. & Brazil & L. Clark 1299, ISC & AF164381 \\
\hline \multicolumn{4}{|l|}{ Streptochaeteae } \\
\hline Streptochaeta angustifolia Soderstr. & Brazil & L. Clark 1304, ISC & AF164382 \\
\hline Streptochaeta spicata Schrad. ex Nees & Brazil & MBG 93091/K. Hilu 0001, VPI & AF 164383 \\
\hline \multicolumn{4}{|l|}{ Arundinoideae } \\
\hline \multicolumn{4}{|l|}{ Aristideae } \\
\hline Aristida adscensionis L. & Pakistan & PI 269867/K. Hilu 5516, VPI & AF164412 \\
\hline Aristida latifolia Domin & Australia & J. Dalby $97 / 12$, NSW & AF 164413 \\
\hline \multicolumn{4}{|l|}{ Arundineae } \\
\hline Arundo donax L. & unknown & K. Hilu 5546, VPI & AF164408 \\
\hline Centropodia glauca (Nees) Cope & Namibia & N. Barker 967, BOL & AF 164410 \\
\hline Danthonia spicata (L.) P. Beauv. ex Roem. \& Schult. & VA-USA & J. Randall (seed)/K. Hilu 5505, VPI & AF164409 \\
\hline Molinia caerulea (L.) Moench & Germany & BBG 13977/T. Borsch 3320, VPI & AF164411 \\
\hline Phragmites australis (Cav.) Trin. ex Steud. & VA-USA & G. Fleming s.n., VPI & AF 144575 \\
\hline \multicolumn{4}{|l|}{ Bambusoideae } \\
\hline \multicolumn{4}{|l|}{ Bambuseae } \\
\hline Chusquea coronalis Soderstr. \& C. E. Calderón & unknown & MBG 896581/K. Hilu 0002, VPI & AF164389 \\
\hline Phyllostachys aurea Rivière \& C. Rivière & unknown & K. Hilu 9418, VPI & AF 164390 \\
\hline Sasa kurilensis (Rupr.) Makino \& Shibata & Japan & A. Nishiwaki (seed)/K. Hilu 5774, VPI & AF164391 \\
\hline \multicolumn{4}{|l|}{ Brachyelytreae } \\
\hline Brachyelytrum erectum (Schreb.) P. Beauv. & VA-USA & T. Wieboldt s.n., VPI & AF164384 \\
\hline \multicolumn{4}{|l|}{ Olyreae } \\
\hline Lithachne pauciflora (Sw.) P. Beauv. & Costa Rica? & L. Clark 1297, ISC & AF164385 \\
\hline Olyra latifolia L. & Brazil & L. Clark 1191, ISC & AF 164386 \\
\hline
\end{tabular}




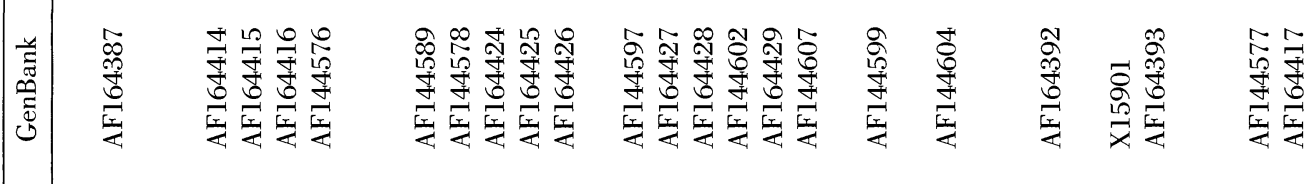

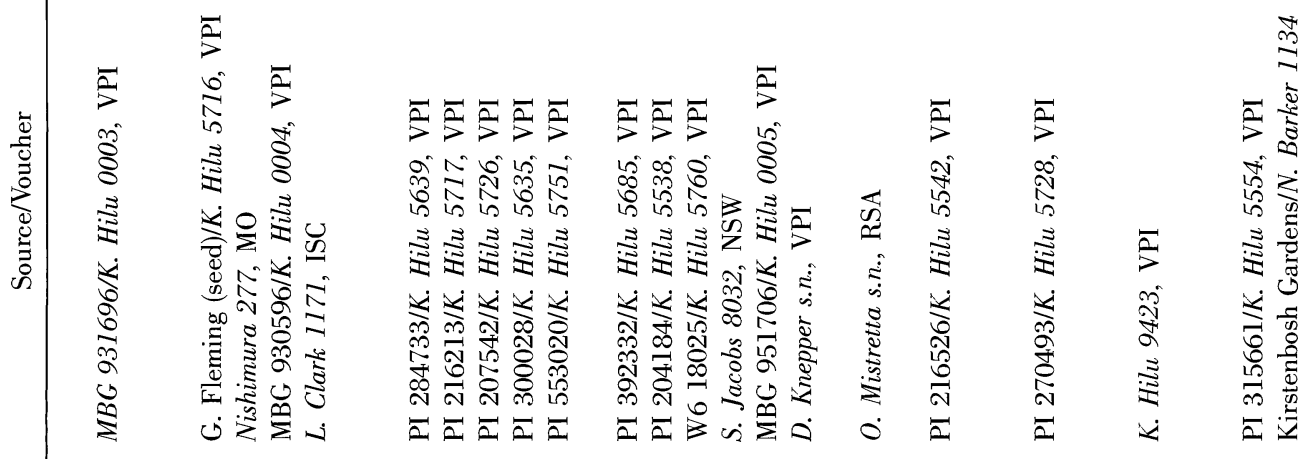

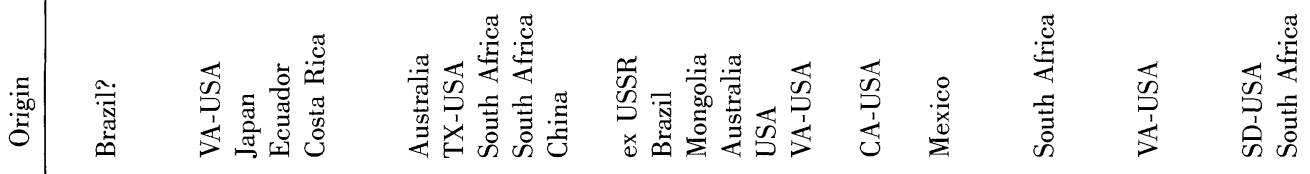

:

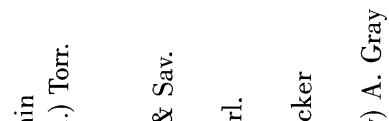

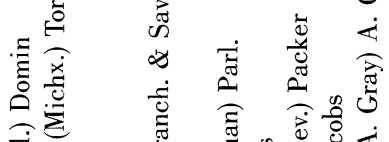

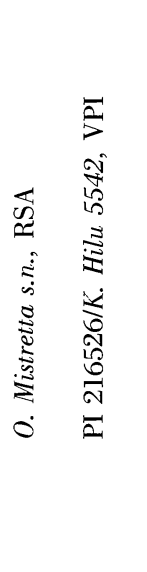

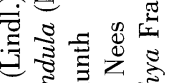

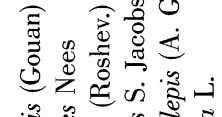

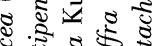

要 8

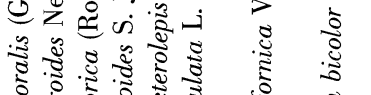

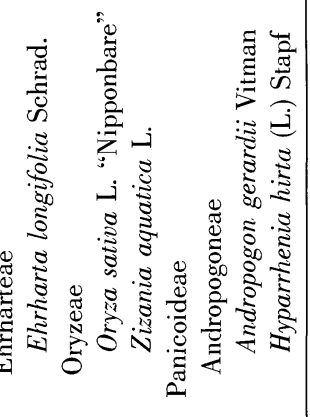




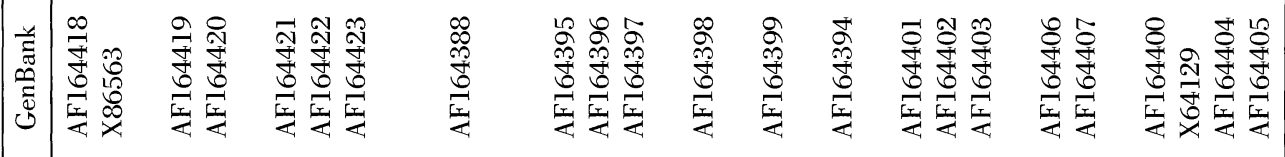

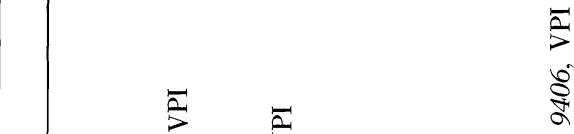

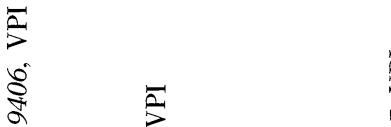

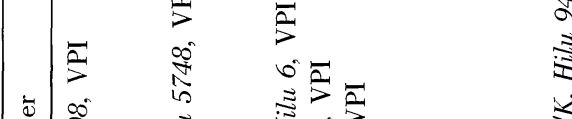

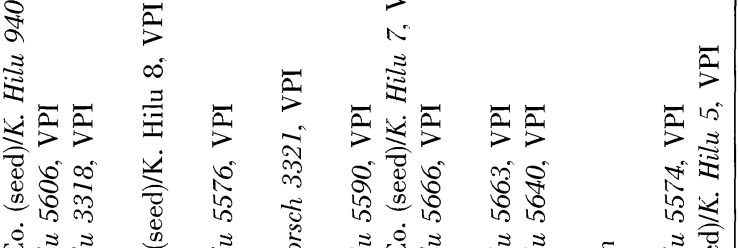

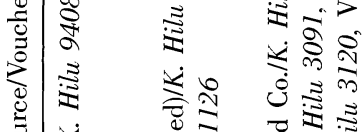

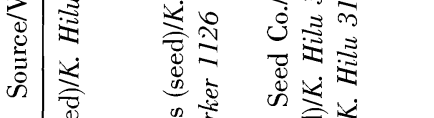

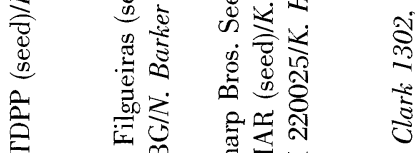

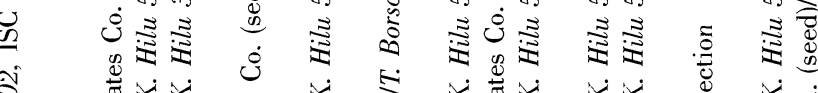
击芯造

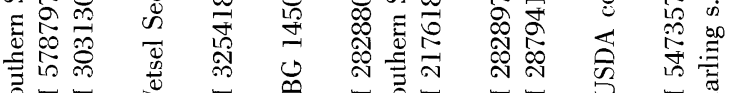

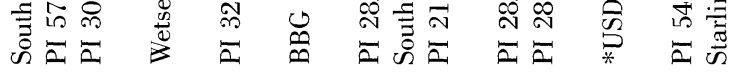

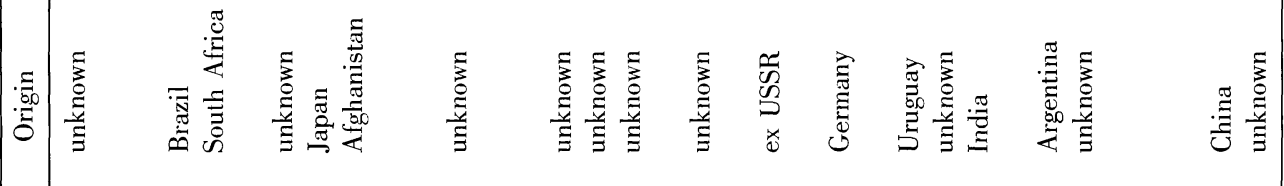

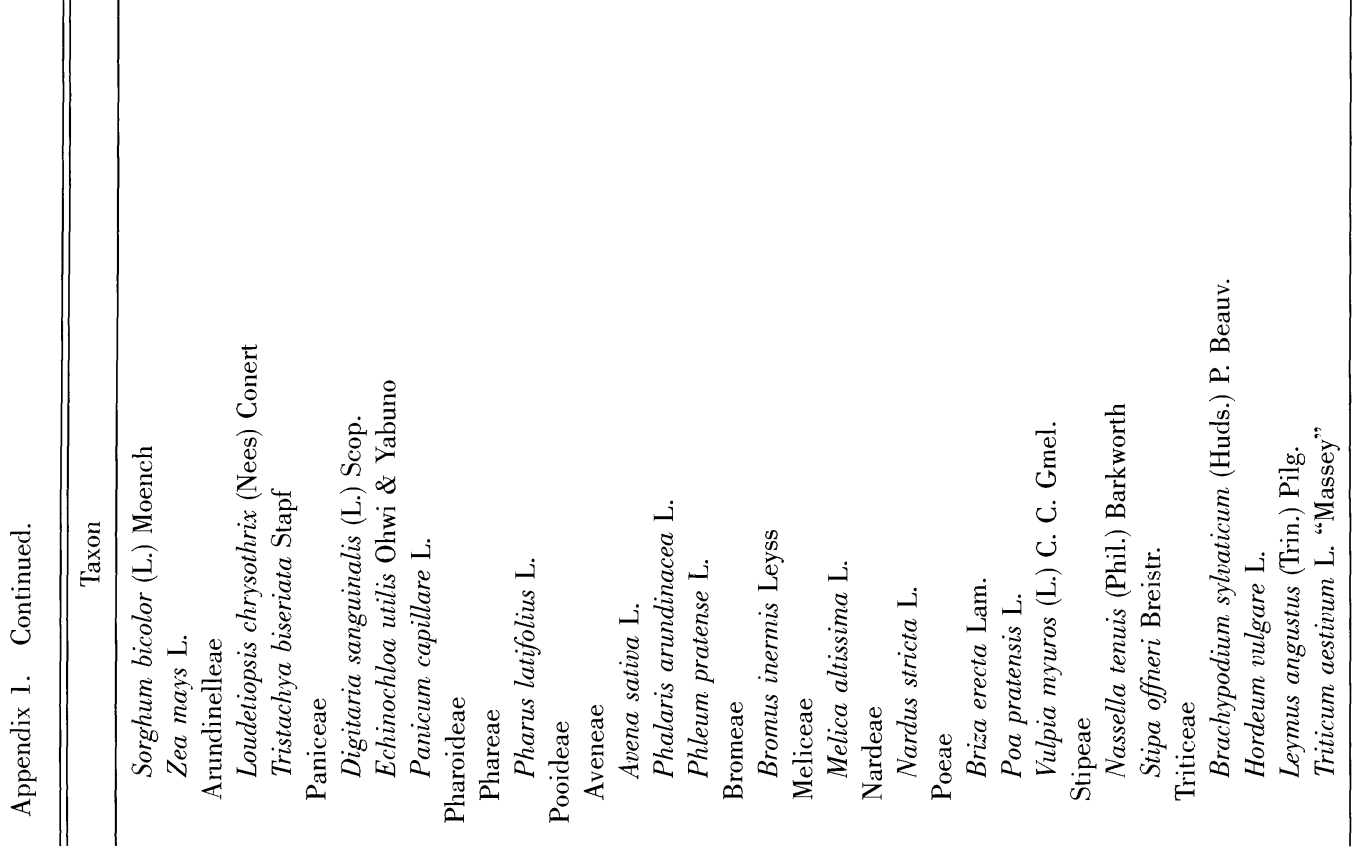

